\title{
Przebaczenie i pojednanie pomiędzy Polakami i Niemcami jako dar i zadanie. W 50 lat po wymianie listów biskupów polskich i niemieckich
}

Redakcja czasopisma „Paedagogia Christiana” przygotowuje aż dwa kolejne numery poświęcone znaczeniu przebaczenia w procesie wychowania i w pedagogice, w ujęciu interdyscyplinarnym, międzyreligijnym, społecznym na użytek pedagogiczny i wychowawczy. Tematyka ta zbiega się czasowo z jubileuszem 50-lecia wymiany listów biskupów polskich i niemieckich z 1965 roku. Zarówno w pamięci historycznej Polaków, jak i Niemców list ten utrwalił się w brzmieniu „Przebaczamy i prosimy o wybaczenie”.

Nie umiem powiedzieć, czy zbieżność tych dwóch faktów w jakimś stopniu jest ze sobą powiązana. Wydaje mi się jednak, że w temacie przebaczenia pominięcie listu biskupów polskich do biskupów niemieckich, który stał się jednym z najbardziej dalekosiężnych i znaczących wydarzeń naszej powojennej polsko-niemieckiej historii (tak uważa między innymi prof. Jan J. Lipski), mogłoby zostać źle zrozumiane. List ten stanowi bowiem najwymowniejszą ilustrację, jak wielkie znaczenie odgrywa właśnie przebaczenie w pojednaniu pomiędzy narodami nie tylko w wymiarze ściśle religijnym, ale także społecznym i politycznym.

* Ks. abp prof. dr hab. Henryk J. Muszyński, arcybiskup senior archidiecezji gnieźnieńskiej, Prymas Polski Senior. Adres: ul. Jana Łaskiego 5, 62-200 Gniezno; e-mail: henryk. muszynski@archidiecezja.pl. 
Te dwa pojęcia: przebaczenie i pojednanie, są ze sobą ściśle złączone i warunkują się wzajemnie. Powojenna historia narodów Polski i Niemiec ilustruje wymownie, jak wielkie znaczenie może mieć akt przebaczenia we wzajemnych, międzyludzkich, sąsiedzkich i międzynarodowych relacjach. Pół wieku, jakie upłynęło od napisania przez biskupów polskich listu do biskupów niemieckich, daje również wystarczającą perspektywę czasową, by ocenić owoce zrodzone z tego wielkodusznego i wręcz profetycznego aktu. Nie ulega wątpliwości, że proces pojednania pomiędzy Polakami i Niemcami, zrodzony z wzajemnego przebaczenia zbrodni i win okresu wojennego, posiada również ważne znaczenie wychowawcze i pedagogiczne dla przyszłych pokoleń.

\section{Inspiracja i źródło „Orędzia...” o przebaczeniu}

Głównym źródłem inspiracji napisania przez biskupów polskich orędzia o przebaczeniu był podwójny moment dziejowy: zakończenie II Soboru Watykańskiego i przygotowanie do obchodów Millenium Chrztu Polski w 1966 roku. Przeżycie głębokiej wspólnoty braterskiej i eklezjalnej komunii z biskupami całego świata zrodziło pragnienie zaproszenia biskupów z innych krajów na uroczystości Tysiąclecia Chrztu Polski.

Kościół w Polsce przygotowywał się do obchodów milenijnych przez Wielką Nowennę pod patronatem Matki Bożej Częstochowskiej w latach 1957-1965. Chrzest jako fundament religijnej wspólnoty wszystkich ochrzczonych zobowiązywał, by nie zacieśniać obchodów wyłącznie do wymiaru narodowego, a nakazywał poszerzyć zaproszenie na najbliższych sąsiadów, także Niemców. Ten szczególny „nakaz chwili” - jak napisali biskupi w „Orędziu...” - sprawił, że:

w tym jak najbardziej chrześcijańskim, ale i bardzo ludzkim duchu, wyciągamy do Was (biskupów niemieckich), siedzących tu, na ławach kończącego się Soboru, nasze ręce oraz udzielamy wybaczenia i prosimy o nie. A jeśli Wy, niemieccy biskupi i Ojcowie Soboru, po bratersku wyciagnięte ręce ujmiecie, to wtedy dopiero będziemy mogli ze spokojnym sumieniem obchodzić nasze Millenium w sposób jak najbardziej chrześcijański ${ }^{1}$.

${ }^{1}$ „Orędzie biskupów polskich do ich niemieckich braci w Chrystusowym urzędzie pasterskim”, w: Listy pasterskie Episkopatu Polski 1945-2000, cz. 2, red. Piotr Libera, Andrzej Rybicki, Sylwester Łącki (Marki-Struga: Michalineum, 2003), 2225-2226. Faksymile „Orę- 
Najpełniejszym i najbardziej fundamentalnym znakiem jedności, zarówno $\mathrm{w}$ wymiarze teologicznym, jak i eklezjalnym, jest i pozostanie na zawsze chrzest święty. Na mocy chrztu świętego powstaje żywy organizm eklezjalny, stanowiący Ciało Chrystusa (gr. Soma tou Christou). Ta jedność i wspólnota jest dziełem samego Boga. Zaświadcza o tym wymownie św. Paweł, stwierdzając: „w Chrystusie Bóg pojednał świat ze sobą i zlecił nam posługę jednania" (gr. diakonia tes katallegēs, łac. ministerium reconciliationis, por. 2 Kor 5, 18).

Głównym źródłem inspiracji do wyciągnięcia rąk i skierowania prośby o przebaczenie była wspólnota wypływająca właśnie z chrztu świętego i pasterska świadomość misji jednania, zlecona apostołom przez Chrystusa. Pojednanie to ma potrójny wymiar: pojednanie z Bogiem, z samym sobą i bliźnimi. Bez wyciągniętej ręki i gotowości przebaczenia właśnie w stosunku do Niemców nie mogło być mowy o wiarogodnym pojednaniu. Wymagało to ogromnej odwagi ze strony biskupów. Symboliczny wymiar i wyjątkowe znaczenie tego gestu wyrażało się w tym, że gotowość przebaczenia i prośba o wzajemność przyszła ze strony Kościoła w Polsce, którego naród był pierwszą ofiarą wojny, a nie od oprawców. Pamięć zbrodni wojennych i rany zadane przez nie były ciagle jeszcze bardzo żywe; wielu, jeżeli nie większość, w imieniu których biskupi wypowiedzieli te słowa, nie było gotowych do przebaczenia. Nie był to oczywiście przełom, ale zwrot i początek dialogu oraz procesu, który zaowocował wzajemnym zbliżeniem.

Dnia 5 grudnia 1965 roku biskupi niemieccy odpowiedzieli na list biskupów polskich:

Na końcu Waszego listu znajdują się cenne słowa, mogące otworzyć nową przyszłość dla naszych dwóch Narodów: „Z ław kończącego się Soboru wyciągamy ku Wam nasze ręce i przebaczamy oraz prosimy o przebaczenie". Z braterskim szacunkiem podejmujemy wyciagnięte dłonie. Bóg Pokoju zaś niech za przyczyną Regina Pacis sprawi, by upiór nienawiści już nigdy nie rozłączył naszych rąk ${ }^{2}$.

dzia" w: Pamięć i przebaczenie. Orędzie biskupów polskich do biskupów niemieckich i jego reperkusje, red. Damian Bednarski (Katowice: Księgarnia św. Jacka, 2015), 164-173.

2 „Pozdrowienie biskupów niemieckich dla polskich braci w biskupim posłannictwie i odpowiedź na list z dnia 18 listopada 1965 roku”, w: Listy pasterskie Episkopatu Polski 1945-2000, cz. 2, red. Piotr Libera, Andrzej Rybicki, Sylwester Łącki (Marki-Struga: Michalineum, 2003), 2230. 
Odpowiedź była uprzejma, ale powściągliwa, zachowawcza i daleka od oczekiwanej przez biskupów polskich. Zabrakło w niej przede wszystkim ustosunkowania się do granicy polsko-niemieckiej na Odrze i Nysie Łużyckiej. Biskupi polscy wskazywali wyraźnie, że jest to sprawa egzystencjalno-bytowa dla narodu polskiego.

Pewna część ludności niemieckiej uznała prośbę biskupów polskich o przebaczenie jako przeproszenie za krzywdy wyrządzone, za sam fakt i okoliczności towarzyszące wygnaniu Niemców w 1945 roku.

W obliczu tych nieporozumień i w odpowiedzi na gwałtowna, antykościelną kampanię komunistycznych władz Polski, oskarżających biskupów, a szczególnie kard. Stefana Wyszyńskiego nawet o zdradę Ojczyzny, ówczesny arcybiskup metropolita krakowski i późniejszy kardynał Karol Wojtyła, prawie bezpośrednio po powrocie z Soboru zaczął tłumaczyć i wyjaśniać faktyczne motywy biskupów w przygotowaniu listu i prośby o przebaczenie skierowanej do biskupów niemieckich.

Trzeba pamiętać, że całe społeczeństwo znało treść listu biskupów jedynie z ocenzurowanej oficjalnej prasy, która zawsze była zaopatrywana odpowiednimi komentarzami. Stąd łatwo było wzbudzać nastroje antykościelne w szerokich kręgach społecznych, nawet pośród księży.

\section{Chrześcijaństwo religią przebaczenia}

W tej sytuacji ówczesny arcybiskup metropolita krakowski Karol Wojtyła w homilii z okazji uroczystości św. Szczepana jeszcze w 1965 roku zwrócił uwagę, że aby ocenić treść listu, trzeba się z nim najpierw zapoznać w całości, „,bez skreśleń i bez zmian”. Następnie wyjaśnił, że przebaczenie i zapomnienie to dwa całkowicie różne pojęcia: trzeba przebaczyć innym, bo Bóg w odpowiedzi na naszą prośbę: ,przebacz nam nasze winy, jak i my przebaczamy tym, którzy przeciw nam zawinili” (Mt 6, 12), nam przebaczył. Przebaczyć nie oznacza jednak zapomnieć:

Te dwa pojęcia (przebaczenie i zapomnienie), zarówno list biskupów polskich do niemieckich, jak też odpowiedź biskupów niemieckich, bardzo wyraźnie rozróżnia. Jest to mianowicie pojęcie zapomnienia i pojęcie przebaczenia. Bardzo często te dwa pojęcia, które wskazują na dwa zupełnie różne fakty wewnętrzne, na dwa różne stany ducha ludzkiego, na dwie różne postawy - bywają używane zamiennie. Tymczasem czymś zupełnie innym jest zapomnieć - to fakt jakby fizyczny. Wynika z innego faktu, mianowicie z tego, że człowiek i jego świa- 
domość są umieszczone w czasie i w czasie się rozwijają. Czas odsuwa nas od pewnych wydarzeń osobistych, zbiorowych, od wydarzeń radosnych, od wydarzeń przykrych i sprawia, że my te wydarzenia zapominamy. Czymś innym jest przebaczenie. Przebaczenie jest faktem wewnętrznym, który dokonuje się w człowieku, w jego duchu, w jego świadomości, w jego woli, a znaczenie tego faktu jest moralne. Przebaczenie należy do całokształtu moralności - zwłaszcza chrześcijańskiej. W chrześcijańskiej moralności przebaczenie jest bardzo wyraźnie i mocno zaakcentowane. Można nawet powiedzieć, że chrześcijaństwo jest religią przebaczenia. Ale przebaczenie takie, jakiego uczy nas Chrystus, nie jest równoznaczne z zapomnieniem. I powiem, że może istnieć zapomnienie bez przebaczenia i też na odwrót: może istnieć przebaczenie bez zapomnienia. Można przebaczyć - pamiętając; autentycznie przebaczyć - pamiętając. Można zapomnieć - nie przebaczając. To są dwa różne fakty wewnętrzne. Jeżeli każdy z nas wniknie w siebie, w swoje sumienie, w swoją świadomość, to ta świadomość potwierdzi mu różnicę owych faktów ${ }^{3}$.

Być może jest to odpowiedź na stwierdzenie biskupów niemieckich, którzy odwołując się do tego samego tekstu Modlitwy Pańskiej, napisali:

O przebaczenie Jego (Boga) trzeba przede wszystkim prosić. Do Niego na pierwszym miejscu skierowana jest prośba z Ojcze nasz: „Odpuść nam nasze winy". Następnie zaś wolno nam ze szczerego serca prosić o przebaczenie naszych sąsiadów. Tak też prosimy i my o zapomnienie, więcej, prosimy o przebaczenie. Zapomnienie jest sprawą ludzką, natomiast prośba o przebaczenie jest apelem skierowanym do tego, kto doznał krzywdy, by spojrzał na tę krzywdę miłosiernym okiem Boga i wyraził zgodę na nowy początek ${ }^{4}$.

Wypełnienie tej prośby, by zapomnieć przed przebaczeniem, jest trudne czy wręcz niemożliwe do wykonania. Pamięć jest bowiem częścią tożsamości zarówno w wymiarze indywidualnym, jak i społecznym. Zachowanie pamięci z kolei jest niezbędnym warunkiem leczenia pamięci (healing of memory), które warunkuje prawdziwe pojednanie. Bez wyleczenia nie ma uzdrowienia.

${ }^{3}$ Karol Wojtyła, Kazanie w kościele św. Szczepana, Kraków, 26 grudnia 1965 r., w: Odnowa Kościoła i świata. Refleksje soborowe, red. Andrzej Dobrzyński (Kraków-Rzym: Wydawnictwo św. Stanisława BM, 2011), 298-299.

4 „Pozdrowienie biskupów”, 2228-2229. 
W dalszej części swego kazania abp Karol Wojtyła przypomniał, że przebaczenie to ,jeden z pierwszych nakazów moralności chrześcijańskiej” i wyjaśnił, na czym polega ,struktura przebaczenia Chrystusowego":

Przebaczenie według nauki Chrystusa jest zasadą moralną, której w życiu ludzkim odpowiada pewna struktura. Strukturę tę doskonale znamy i stosujemy. Stosujemy ją zawsze, kiedy przychodzimy do spowiedzi. Struktura ta pochodzi od samego Boga. Bóg sam przez Chrystusa nauczył nas, jak mamy postępować, ażeby On nam przebaczył. Wiemy, że gdy mamy przystapić do sakramentu pokuty, to po rachunku sumienia musimy przede wszystkim wzbudzić żal za grzechy i postanowić poprawę. To są właśnie istotne warunki pokuty wszelkiej $\mathrm{i}$ istotne warunki sakramentu pokuty. Taka jest struktura przebaczenia Chrystusowego. Można powiedzieć, że w Ewangelii nie ma łatwego przebaczenia. W Ewangelii zawiera się nakaz przebaczenia jako jeden z pierwszych nakazów moralności chrześcijańskiej, ale nie ma „łatwizny przebaczeń”. To jest znowu zgodne z prawami ludzkiej natury, z godnością człowieka, z jego głębią. Żeby przebaczyć, trzeba naprawdę znaleźć drogę do dobra, trzeba zacząć od nowa, trzeba wycofać się ze zła - to wszystko są warunki przebaczenia. Taka jest chrześcijańska, Chrystusowa nauka o przebaczeniu ${ }^{5}$.

Na koniec homilii wygłoszonej w uroczystość Bożego Narodzenia w katedrze wawelskiej abp Karol Wojtyła, w nawiązaniu do stawianych przez władze komunistyczne polskim biskupom zarzutów, wyjaśnił, że list wylicza także krzywdy wyrządzone narodowi polskiemu w ciągu wieków, szczególnie w czasie ostatniej wojny: „wyznaliśmy sami i opisaliśmy sami aż po Oświęcim, aż po sześć milionów ofiar ostatniej wojny, nie ukrywając niczego i nie pomniejszając niczego”. Dopiero pod sam koniec, „w jednym zdaniu, powiedzieliśmy im »dajemy przebaczenie i prosimy o przebaczenie«" (niem.: gewähren Vergebung und bitten um Vergebung). W zrozumieniu abpa Wojtyły ta formuła nie jest oczywiście dziełem przypadku, bo w niej ,wyznaliśmy sami, żeby łatwiej im (biskupom niemieckim) było wyznać (...), jak bardzo oni, przez to nasze wyznanie za nich, sami uczynili wyznanie" $"$

5 Wojtyła, Kazanie w kościele św. Szczepana, 299.

${ }^{6}$ Karol Wojtyła, Kazanie w katedrze wawelskiej, 25 grudnia 1965 r., w: Odnowa Kościoła i świata. Refleksje soborowe, red. Andrzej Dobrzyński (Kraków-Rzym: Wydawnictwo św. Stanisława BM, 2011), 295. 
Przebaczenie w najgłębszej swojej istocie jest dziełem miłości, miłości Boga, który przebacza, i człowieka, który przekazuje je i dzieli się otrzymanym darem. W czasie apelu jasnogórskiego w Częstochowie w roku 1983 Jan Paweł II powiedział między innymi:

Przebaczenie jest mocne mocą miłości,

Przebaczenie nie jest słabością.

Przebaczać nie oznacza rezygnować z prawdy i sprawiedliwości.

Oznacza zmierzać do prawdy i sprawiedliwości drogą Ewangelii

\section{Wspólnotowy i spoleczny wymiar przebaczenia}

Przebaczenie w zrozumieniu chrześcijańskim jest aktem głęboko religijnym i wewnętrznym, nie może się ono dokonać tylko przy pomocy deklaracji, oświadczeń czy dokumentów. Gotowość przebaczenia musi zostać wewnętrznie zaakceptowana w sumieniu człowieka. Wielu Polaków nie rozumiało, dlaczego my, jako pierwsze ofiary okrutnej wojny, mamy przepraszać Niemców. Świadomość popełnionych przez Niemcy zbrodni i krzywd wyrządzonych Polakom w czasie okupacji sprawiała, że wielu pytało, za co mamy przepraszać, a innych nie stać było na akt przebaczenia.

Propaganda komunistyczna przez fałszywe oskarżenia i oczernianie, kierowane ustawicznie przeciwko biskupom polskim, potęgowała jeszcze świadomość doznanych zbrodni, krzywd i niesprawiedliwości. Ówczesne władze państwowe umiejętnie wykorzystywały tę sytuację do zorganizowania protestów zarówno ludzi świeckich, jak i duchownych, skierowanych przeciwko katolickim biskupom, a szczególnie przeciwko prymasowi Wyszyńskiemu. Jak świadczą o tym choćby zapiski osobiste Księdza Prymasa, cierpiał bardzo z tego powodu, oskarżenia nazywał ich właściwym określeniem „kłamstwa” lub „oszczerstwa”, prosił wiernych o zaufanie i przyjął taktykę milczenia. W jednym z kazań w Warszawie powiedział:

Nie spodziewam się, najmilsi, dla siebie niczego dobrego. Tylko Was proszę o jedno: miejcie odrobinę zaufania do swojego biskupa, który umiał walczyć, gdy było potrzeba w obronie Ojczyzny. Jestem także żołnierzem. Brałem udział

7 Jan Paweł II, Apel jasnogórski, 19 czerwca 1983 r., w: Dzieła zebrane, t. 9: Homilie i przemówienia z pielgrzymek - Europa, cz. 1: Polska, red. Paweł Ptasznik (Kraków: Wydawnictwo M, 2008), 235. 
w powstaniu. (...) I jestem przekonany, że na to, co dziś przeżywam, nie zasłużyłem sobie w mojej Ojczyźnie. Ale jeżeli tak się dzieje, to w Imię Boże wszystkim moim oszczercom - bo inaczej nazwać ich nie mogę-przebaczam! Niech oni to wiedzą, że im przebaczam, jak przebaczam wszystkim, którzy usiłują moją prawdę na swój sposób przedstawić. Tak czyni chrześcijanin, a ja chcę być chrześcijaninem ${ }^{8}$.

W tej napiętej sytuacji, gdy wielu wiernych oficjalnie protestowało przeciwko „Orędziu...”, prymas Wyszyński umiejętnie wykorzystał centralne obchody milenijne na Jasnej Górze, w uroczystość Matki Bożej Królowej Polski 3 maja 1966 roku. Najpierw w czasie uroczystej Mszy św. wyjaśnił właściwy, religijny sens milenijnych uroczystości i zobowiązań płynących z przyjęcia chrztu świętego, zarówno w wymiarze indywidualnym, jak i wspólnotowym. Przypomniał o dziewięcioletniej Nowennie, która miała przygotować naród na oddanie w ,macierzyńską niewolę Maryi za wolność Kościoła jako żywe wotum wdzięczności narodu"9.

Wieczorem, w czasie apelu jasnogórskiego, Ksiądz Prymas najpierw przypomniał,

że pierwszym słowem nowego tysiąclecia jest przykazanie: abyście sie społecznie miłowali. Po przywołaniu wymownych fragmentów z polskiej literatury „ukazującej najpiękniejszą stronę polskiej duszy”, która umie przebaczać, jak „Sąd nad Bugajem” z Bolestawa Chrobrego A. Gołubiewa, przebaczenie Juranda z Krzyżaków H. Sienkiewicza, czy wstrząsający fragment o przebaczeniu R. Brandstaettera, ks. Prymas skończył apel jasnogórski słowami: „Wsłuchajmy się w ostatnie słowa Chrystusa, skierowane do Ojca, w obronie tych, którzy Go ukrzyżowali: Ojcze, odpuść im, bo nie wiedza, co czyniq. Z Jasnej Góry Zwycięstwa przezwyciężając samych siebie, wołamy - my, biskupi polscy i lud Boży: Przebaczamy!" A cały lud powtórzył wyraźnie: przebaczamy! Podejmując słowa Księdza Prymasa modlitwy do Ojca niebieskiego: i odpuść nam nasze winy, tłumy zgromadzone pod wałami jasnogórskimi podchwyciły, wołając: i odpuść nam nasze winy, jako i my odpuszczamy naszym winowajcom! ${ }^{10}$.

${ }^{8}$ Władysław Ziemba, Stefan Kardynat Wyszyński. Biografia w fotografiach (Orchard Lake: Zakłady Naukowe Seminarium Polskiego, 1969), 231.

9 Peter Raina, ,, Te Deum” narodu polskiego. Obchody tysiaclecia chrztu Polski 1966/67 (Olsztyn: Warmińskie Wydawnictwo Diecezjalne, 1991), 125-126.

${ }_{10}$ Por. Ziemba, Stefan Kardynat, 246-247; por. też. Raina, „Te Deum” narodu polskiego, 127. 
Odpowiedź udzielona prymasowi Wyszyńskiemu nie oznaczała oczywiście natychmiastowej, magicznej zmiany postawy Polaków. Nie tylko bezpośredni uczestnicy, ale także wszyscy ochrzczeni, którzy zainteresowali się tym symbolicznym obrzędem przebaczenia, mogli się przekonać, jakie były faktyczne motywy gestu biskupów udzielających przebaczenia i proszących także o przebaczenie biskupów niemieckich. Pogłębiło to zapewne również religijną świadomość wielu, że dar i łaska chrztu świętego wraz z przebaczeniem otrzymanym od Boga stanowią wielkie zobowiązanie użyczania przebaczenia tym, którzy wobec nas zawinili.

W tym momencie Ksiądz Prymas okazał niezwykłą odwagę zarówno w stosunku do władz, jak i wielu wiernych Kościoła katolickiego, którzy pozostawali pod wpływem propagandy komunistycznej. Nade wszystko skłonił wielu, szczególnie kapłanów, do pogłębionej refleksji i próby rozliczenia się z przeszłością, kładąc jednocześnie trwały fundament do odbudowania zaufania, zbliżenia się i pojednania naszych Kościołów i narodów. Okazał się raz jeszcze w tym momencie prawdziwym ojcem narodu i uzyskał ze strony olbrzymiej większości wiernych ogromny kredyt zaufania, który wzmocnił jego pozycję w odniesieniu do władz komunistycznych.

Po powrocie z Soboru Prymas Stefan Wyszyński w Warszawie, podobnie jak arcybiskup Karol Wojtyła w Krakowie, podczas uroczystości Bożego Narodzenia 25 grudnia 1965 roku thumaczył wiernym:

Dziwią się ludzie biskupom katolickim, że wzywają do przebaczenia. To jest chyba dowód jakiegoś spoganienia. Na szczęście jest to spoganiałość oficjalna, a nie spoganiałość Narodu, który umie przebaczać i nie raz w swych dziejach, aby rozładować nienawiść - przebaczał. Najmilsi, i my do tego programu Chrystusowego się przyznajemy. Jeśli ludzkość nie ma się zaprzepaścić we wzrastającej nienawiści, potęgowanej i propagowanej, to musi się zdobyć na męstwo, na wielką chrześcijańską odwagę przebaczenia. Zacznijcie tę cnotę uprawiać w swoim sercu wobec najbliższego wam otoczenia, wobec waszych rodzin, mężów, żon i dzieci, wobec waszych współpracowników, zwierzchników i podwładnych. Wszędzie, gdziekolwiek jesteście, doświadczajcie społecznej mocy Chrystusowego ducha, a zobaczycie, że sami doznacie ulgi i przyniesiecie ją otoczeniu i całemu światu ${ }^{11}$.

${ }^{11}$ Stefan Wyszyński, Fragment życzeń wygłoszonych w bazylice katedralnej św. Jana w Warszawie, 25 grudnia 1965 r., w: Budowniczy mostów pojednania. Kardynat Bolesław Kominek (1903-1974), red. Patryk Gołubców, Urszula Pohl, Bożena Sobota (Wrocław: Wydawnictwo TUM Wrocławskiej Księgarni Archidiecezjalnej, 2015), 146-147. 
W przededniu milenijnych uroczystości na Jasnej Górze ówczesny abp Bolesław Kominek tak wyjaśniał uniwersalne, ponadczasowe znaczenie przebaczenia dla powszechnego braterstwa:

Wyznajemy prawdziwe i powszechne braterstwo - nie zacieśnione do szczegółów jednego narodu, tym więcej, do jednej grupy; wyznajemy braterstwo wobec przyjaciół i nieprzyjaciół. Mimo oporu niektórych uczuć, mimo krwawiących jeszcze serc po wojennych krzywdach, głosimy potrzebę sprawiedliwości, odpowiedzialności za winy, a równocześnie głosimy przebaczenie i braterstwo wobec wszystkich ludzi dobrej i szlachetnej woli. Nie wolno nikomu wpychać naszej wiary powszechnej, Chrystusowej, w ciasne, nacjonalistyczne getto, getto bez wyjścia; nie wolno nam ograniczać żadną miarą tego, co mamy w dziele Odkupienia najlepszego - chrześcijańskiego przykazania miłości ${ }^{12}$.

Problem przebaczenia został podjęty także przez innych biskupów polskich po zakończeniu Soboru. Gotowość przebaczenia stanowiła jeden z głównych tematów, obok problemu granicy na Odrze i Nysie i odpowiedzi na pytanie: w czyim imieniu przemawiali księża biskupi, kierując swój list do niemieckich braci w biskupim posłannictwie?

W słowie biskupów polskich o listach do Episkopatów na temat Millenium z 10 lutego 1966 roku, skierowanym do wiernych Kościoła katolickiego po zakończeniu Soboru, hierarchowie zwracają uwagę, że słowa ,przebaczamy i prosimy o przebaczenie" można zrozumieć jedynie w duchu wiary, w świetle nowego przykazania, którego nie zna żadna inna religia: „miłujcie waszych nieprzyjaciół i dobrze czyńcie tym, którzy was nienawidzą" (Mt 5, 44).

Mieliśmy chrześcijańską odwage - piszą biskupi - wykazać jasno społeczności niemieckiej jej grzechy wobec naszej społeczności narodowej (...). Wyraziliśmy słowa przebaczenia dla tych, którzy winę swoją rozumieją i mają dobrą wolę pokojowego wspólistnienia z nami (...). Przebaczyliśmy tak, jak przebaczył Chrystus na krzyżu (...).

Czy Naród polski ma powód do tego, by prosić swych sąsiadów o przebaczenie? Zapewne, nie! Jesteśmy przekonani, że jako naród nie wyrządziliśmy przez wieki narodowi niemieckiemu krzywd politycznych, gospodarczych i kulturalnych. Ale też wyznajemy chrześcijańską zasadę, tak podkreślaną również w niektórych dziełach literatury, że nie ma ludzi niewinnych (Albert Camus). Jesteśmy przekonani, że gdyby nawet tylko jeden Polak okazał się człowiekiem

12 Raina, „Te Deum” narodu polskiego, 134. 
niegodnym, gdyby nawet tylko jeden w ciągu historii spełnił czyn niegodny, już mielibyśmy powód do wyrażenia: przepraszamy, jeżeli chcemy być narodem ludzi szlachetnych i wielkodusznych, narodem lepszej przyszłości ${ }^{13}$.

Biskupi przyznaja, że jest to próba ogniowa dla całego narodu i bodaj najtrudniejszy egzamin dziejowy. Niech zatem każdy we własnym sumieniu odpowie: „czy zdolny jest myśleć i oceniać sprawy po chrześcijańsku? Nasza wiara musi niekiedy przechodzić wewnętrzne próby w naszym prywatnym życiu, musi też stać się «widowiskiem dla ludzi i aniołów» - jak mówi Pismo Święte"14.

\section{Przebaczenie, które otwiera drogę dialogu, pojednania i współpracy}

Gotowość przebaczenia stanowiła pierwszy i bez wątpienia najważniejszy krok ku odbudowaniu wzajemnego zaufania i otworzyła drogę do nawiązania kontaktów i pasterskiego dialogu pomiędzy Episkopatami Polski i Niemiec. Był to oczywiście trudny, długotrwały proces, którego skutki dostrzegamy dopiero dziś, po pół wieku.

W stylu telegraficznym pozwolę sobie przywołać jedynie najważniejsze etapy tej drogi w wymiarze kościelnym. Pierwsze kontakty pomiędzy prymasem Stefanem Wyszyńskim i kard. Juliuszem Döpfnerem zostały nawiązane już w Rzymie, w czasie trwania Soboru. W roku 1970 został nawiązany między nimi kontakt listowny. W 1973 roku kard. Döpfner złożył pierwszą wizytę Prymasowi Wyszyńskiemu w Gnieźnie. W 1977 roku ponowił ten sam gest kolejny przewodniczący Konferencji Episkopatu Niemiec, kard. Joseph Höffner.

Dopiero we wrześniu 1978 roku, prawie bezpośrednio przed konklawe, oficjalną wizytę biskupom niemieckim złożyli: kard. Stefan Wyszyński, kard. Karol Wojtyła i arcybiskup poznański Antoni Baraniak. Bezpośrednie kontakty pozwoliły nieco złagodzić istniejące napięcia, a nawet zaowocowały powołaniem w 1978 roku tak zwanej Grupy Kontaktowej Episkopatów Polski i Niemiec, z abpem poznańskim Jerzym Strobą i bpem Essen Franzem

13 „Słowo biskupów polskich o listach do Episkopatów na temat Millenium”, w: Listy pasterskie Episkopatu Polski 1945-2000, cz. 2, red. Piotr Libera, Andrzej Rybicki, Sylwester Łącki (Marki-Struga: Michalineum, 2003), 2236-2237.

14 Tamże, 2235. 
Hengsbachem, dla omawiania dwustronnych, aktualnych problemów duszpasterskich.

Po 30 latach od wymiany listów biskupów polskich i niemieckich i w 50 rocznicę zakończenia II wojny światowej, biskupi Polski i Niemiec wydali pierwszy wspólny dokument. Jako współprzewodniczący zespołu, wespół z kard. Walterem Kasperem, podsunąłem myśl: spróbujmy sprecyzować, za co Niemcy i Polacy poczuwają się do przeproszenia. Mogę zaświadczyć, że nawet po 30 latach odpowiedź na to pytanie była przedmiotem żywej dyskusji i sprawiła spore trudności. Jej owocem jest następujący tekst:

Mamy przed oczyma zbrodniczą agresję narodowosocjalistycznych Niemiec i bezmiar krzywd, jakie w następstwie zostały wyrządzone Polakom przez Niemców. Tą prośbą obejmujemy krzywdę, jaka wskutek wygnania i utraty rodzinnych stron, na mocy decyzji zwycięskich mocarstw, została również wyrządzona wielu Niemcom przez Polaków. Tak oto rozpętana przez hitlerowskie Niemcy przemoc zwróciła się przeciwko własnemu narodowi. Dopiero dzisiaj, kiedy w Polsce można mówić o tym swobodnie, uświadamiamy sobie bezmiar krzywd, które w łączności z tym samym postanowieniem doprowadziły wielu ludzi do utraty ziem ojczystych na Wschodzie ${ }^{15}$.

$\mathrm{W}$ roku 2005, z okazji 40 rocznicy wymiany listów, powstał kolejny wspólny dokument obydwu Episkopatów, w którym czytamy między innymi:

Poruszające i wręcz prorocze słowa: przebaczamy i prosimy o przebaczenie, znacząco wpłynęły na bieg historii. (...). Dar pojednania może stać się naszym udziałem jedynie wówczas, gdy szczerze przyznajemy się do całej prawdy, wzbudzamy żal za przewinienia i uzyskujemy przebaczenie. (...). Tylko prawda może nas wyzwolić (por. J 8, 32); prawda, która niczego nie upiększa i niczego nie pomija, która niczego nie przemilcza i nie dopomina się wyrównania krzywd. (...). Jedynie wtedy, gdy przyznamy się do całej prawdy i jednocześnie wyrzekniemy się ducha wyliczania sobie krzywd, unikniemy jednostronnego patrzenia na własną historię i utorujemy drogę teraźniejszości do owocnej współpracy w przyszłości. (...). Zdajemy sobie sprawę, że ta droga wymaga ogromnego wspólnego wysiłku. By nią kroczyć, potrzeba dobrej woli i rzetelności we wzajemnych kontaktach. Jednak tylko dzięki gotowości pojednania

15 Józef Glemp, Karl Lehmann, „Wspólne słowo polskich i niemieckich biskupów z okazji 30. rocznicy wymiany listów (1965-1995)", L'Osservatore Romano 2 (1996): 56. 
między naszymi narodami może się ugruntować pokój, który przyniesie Polakom i Niemcom upragnione poczucie bezpieczeństwa i prawdziwej przyjaźni ${ }^{16}$.

Proces zbliżenia między narodami Polski i Niemiec, otwarty wymianą listów przez biskupów, utorował drogę do podjęcia dialogu i współpracy także pomiędzy instytucjami i organizacjami, takimi jak: Znak Pojednania (Aktion Sühnezeichen), Caritas, Pomoc Kościołowi w Potrzebie (Kirche in Not), Dzieło Maksymiliana Kolbego (Maximilian Kolbe-Werk) czy fundacja pod tą samą nazwą (Maximilian Kolbe-Stiftung). Współpracę rozszerzono także z czasem na wspólną wymianę polsko-niemieckiej młodzieży, obejmującą zarówno młodzież szkolną, jak i studencką w ramach Jugendwerku.

W ślad za działaniem Kościołów współpracę tę podjęli także politycy. Po formalnym uznaniu na mocy tak zwanego traktatu warszawskiego przez RFN granicy na Odrze i Nysie Łużyckiej w 1970 roku, 28 czerwca 1972 roku Konstytucja Apostolska Episcoporum Poloniae Coetus Pawła VI usankcjonowała status kanoniczny Kościoła katolickiego na Ziemiach Zachodnich i Warmii. Pełną normalizację stosunków polsko-niemieckich przyniósł jednak dopiero wielki demokratyczny przełom w 1989 roku i przyjęcie Polski w roku 2004 do Unii Europejskiej.

Wymownym znakiem tych zmian pozostaną na zawsze symboliczne gesty, jak uklęknięcie kanclerza Willy'ego Brandta przed Pomnikiem Bohaterów Getta w Warszawie dnia 7 grudnia 1970 roku czy znak pokoju pomiędzy premierem Polski Tadeuszem Mazowieckim a kanclerzem Niemiec Helmutem Kohlem w czasie Mszy św. w Krzyżowej (Kreisau) 12 listopada 1989 roku. Niezapomnianym na zawsze pozostanie zburzenie 9 listopada 1989 roku tak zwanego muru berlińskiego, który dzielił Niemcy i Europę czy spotkanie - dziś świętego - Jana Pawła II z kanclerzem Helmutem Kohlem pod Bramą Brandenburską w Berlinie 23 czerwca 1996 roku.

Po zawarciu traktatu między Rzeczpospolitą Polską a Republiką Federalną Niemiec, potwierdzającego istniejące granice na Odrze i Nysie w 1990 roku, i Traktacie o dobrym sąsiedztwie i przyjaznej współpracy w 1991 roku (ratyfikowany w 1992 roku) współpraca ta poszerzyła się także na poszczególne miasta, a nawet pojedyncze parafie.

Pięćdziesiąta rocznica wymiany listów z 1965 roku miała szczególnie uroczysty charakter uwieńczony wspólną celebrą biskupów Polski i Niemiec

16 Józef Michalik, Karl Lehmann, Wspólne oświadczenie Konferencji Episkopatów Polski i Niemiec z okazji 40. rocznicy wymiany listów między oboma episkopatami w roku 1965 (Warszawa: Wydawnictwo Jedność, 2005), 5, 7. 
na Jasnej Górze podczas uroczystości Chrystusa Króla Wszechświata 22 listopada 2015 roku. Została ona uczczona także wspólnym przesłaniem prezydentów Polski i Niemiec: Andrzeja Dudy i Joachima Gaucka, oraz wspólnym oświadczeniem przewodniczących Konferencji Episkopatów Polski i Niemiec: abpa Stanisława Gądeckiego oraz kard. Reinharda Marxa.

Panowie prezydenci w swoim przesłaniu przyznali, że „Orędzie polskich biskupów..." z 1965 roku było:

aktem niezwykłej odwagi, duchowej mądrości i dalekosiężnej wizji, którym przełamali wyliczanie krzywd i klimat wrogości i rozpoczęli proces zbliżenia i dialogu. Dostrzegli również, że treści zawarte w liście biskupów z 1965 roku są nadal aktualne: jesteśmy ze sobą powiązani - jak sąsiedzi i partnerzy w Zjednoczonej Europie. I właśnie wzmacnianie tej więzi jest naszym wielkim zadaniem i wyzwaniem na przyszłość ${ }^{17}$.

W swoim wspólnym oświadczeniu przewodniczący Episkopatów Polski i Niemiec, w odniesieniu do „Orędzia....” napisali:

Kościół uwolnił się wówczas spod politycznego dyktatu zimnej wojny i dał mocny przykład profetycznego realizmu. Nasi poprzednicy, w skrajnie trudnych okolicznościach, zaufali sile prawdy i przebaczenia. Okazali gotowość do nawiązania dialogu $\mathrm{z}$ drugą stroną, posiadającą swoje perspektywy i zranienia. Jeśli dziękujemy dzisiaj ówczesnym biskupom za ich chrześcijańską odwagę i świadectwo wiary, to ogarniamy także pamięcią wielu mężczyzn i wiele kobiet po obu stronach, którzy od lat 60 . stawiali pierwsze kroki ku zbliżeniu, rozpoczynając tę długą, mozolną, niekiedy kamienistą i wyboistą drogę, prowadzącą ostatecznie do codziennej normalności i przyjaźni, która w międzyczasie połączyła nasze narody $(\mathrm{nr} 4)^{18}$.

Arcybiskup Stanisław Gądecki w swoim przemówieniu podkreślił teologiczny wymiar przebaczenia i pojednania jako:

${ }^{17}$ Andrzej Duda, Joachim Gauck, „Kościoły wyprzedziły politykę”. Wspólne przesłanie prezydenta Rzeczypospolitej Polskiej i prezydenta Republiki Federalnej Niemiec na spotkanie Biskupów Episkopatów Polski i Niemiec w Częstochowie z okazji 50. rocznicy powstania „Orędzia polskich biskupów do ich niemieckich braci w Chrystusowym urzędzie pasterskim” z 18 listopada 1965 r., Wiadomości KAI 48 (2015): 8-9.

18 Stanisław Gądecki, Reinhard Marx, „Budować przyszłość w duchu przeżytego pojednania”. Wspólne oświadczenie przewodniczących Konferencji Episkopatów Polski i Niemiec z okazji 50. rocznicy wymiany listów z 1965 r., Wiadomości KAI 48 (2015): 6. 
autentycznego daru pochodzącego od Boga. (...) Kiedy polscy biskupi wystosowali do swoich niemieckich braci list ze słynnym «przebaczamy i prosimy o przebaczenie», w swojej dalekowzroczności wyprzedzili oni epokę i w imię chrześcijańskiej miłości jako pierwsi wyciągnęli ręce do Niemców, choć - wobec ogromu wyrządzonych Polakom krzywd - ten gest winien był wyjść najpierw od Niemców (nr 4).

Arcybiskup Gądecki przypomniał również znane słowa kard. Stafana Wyszyńskiego: „Nienawiść prowadzi na cmentarze, miłość prowadzi do nowego życia"19. Gotowość przebaczenia jest najbardziej wymownym znakiem tejże miłości.

Kardynał Reinhard Marx podkreślił w homilii podczas uroczystej Mszy św. na Jasnej Górze, że list biskupów polskich jest ,jednym z tych listów, które posiadają epokowe znaczenie. Wyciagnięte do siedzących na ławach kończącego się Soboru biskupów niemieckich ręce oraz słowa «udzielamy wybaczenia i prosimy o nie», to wielkie historyczne słowa, które dla Niemców stanowią niezasłużony dar"'20.

W przemówieniu wygłoszonym na Jasnej Górze kard. Reinhard Marx przypomniał najgłębszy teologiczny wymiar przebaczenia, którego źródłem jest Boża miłość, a znakiem krzyż Chrystusa.

Jakże byłoby możliwe nowe współistnienie ponad bezdenną przepaścią winy bez miłości Bożej? - pytał kardynał i wyjaśniał dalej: Wiara chrześcijańska nie zakłada tego, że czas leczy rany i wina kiedyś się w końcu zatrze. Krzyż jest znakiem tego, że winę i jej ciężar traktuje się poważnie, a Bóg musi posunąć się do ostateczności, aby wina nie doprowadziła do trwałego podziału. W tym duchu nasi poprzednicy, biskupi z Polski i z Niemiec, odważyli się na akt przebaczenia, nie pokładając ufności w sobie samych i we własnych siłach, ale w Krzyżu Chrystusowym. Pisząc list do biskupów niemieckich, w którym przebaczali i prosili o przebaczenie, polscy biskupi polegali na Bożej gotowości do przebaczenia. Dla Niemców był to niezasłużony dar po tym, przez co naród polski przeszedł podczas niemieckiej okupacji w czasie drugiej wojny światowej. Dlatego wiele osób uważa, że odpowiedź niemieckich biskupów

19 Stanisław Gądecki, „Bogu niech będą dzięki za nasze dzisiejsze spotkanie”. Przemówienie w kaplicy Domu Pielgrzyma podczas uroczystości z okazji 50. rocznicy listu biskupów polskich do niemieckich, Wiadomości KAI 48 (2015): 11-12.

${ }^{20}$ Reinhard Marx, „Przekazujmy pojednanie dalej”. Homilia przewodniczącego Episkopatu Niemiec, wygłoszona podczas Mszy Świętej odprawionej z okazji 50-lecia wymiany listów między Episkopatami Polski i Niemiec, Wiadomości KAI 48 (2015): 9. 
nie dorównała historycznej sile polskiego pisma, że była zbyt zdystansowana i szorstka. Całkowicie rozumiem tę krytykę. Jednak dla historycznego procesu, dla owocności wymiany listów, tego rodzaju nierówności nie były najważniejsze. Jestem pewien, iż najważniejsze było to, że obie strony dotrzymały tego, co poprzez swój historyczny gest obiecały ${ }^{21}$.

Decydujące jest to, że zarówno biskupi w Polsce, jak i biskupi w Niemczech - mówił kard. Marx w swojej homilii - zadbali o to, aby nienawiść, niezgoda i polityczne kalkulacje nigdy więcej nie zdołały rozdzielić naszych rąk. Pomimo lepszych i gorszych czasów w stosunkach politycznych, pomimo niedorzeczności i rozczarowań, które pojawiły się w relacjach między Kościołem w Niemczech i Kościołem w Polsce, Kościół w obu państwach - nie tylko biskupi, ale również księża i świeccy - pozostali razem. Pragniemy wspólnie kształtować naszą ojczyznę - Europę - oraz przyszłość chrześcijaństwa na naszym kontynencie. Taki był niejako program wymiany listów. Pozostaliśmy mu wierni. Musimy pozostać mu wierni także w przyszłości ${ }^{22}$.

„W duchu profetycznego realizmu" niemiecki kardynał podsunął szereg sugestii, które wzywają do zintensyfikowania rozmów i kontaktów oraz niesienia na miarę możliwości pomocy narodom i Kościołom ogarniętym wojną i konfliktami: na Ukrainie, Bliskim Wschodzie, Bałkanach i byłych terenach Związku Radzieckiego; wszędzie tam, gdzie ludzie oczekują od nas pomocy.

\section{Zakończenie}

Kilka przywołanych w artykule faktów nie wyczerpuje owoców wielkiego, profetycznego gestu przebaczenia biskupów polskich do biskupów niemieckich. Prawdopodobnie biskupi Polski, zdecydowawszy się na ten odważny i śmiały krok w stosunku do biskupów narodu niemieckiego, którego Polska była pierwszą ofiarą wojny, nie zdawali sobie w pełni sprawy, jak daleko będą sięgały następstwa tego gestu.

${ }^{21}$ Reinhard Marx, „Przemówienie wygłoszone w Częstochowie na uroczystości Konferencji Episkopatów Polski i Niemiec z okazji 50. rocznicy wymiany listów”, http://episkopat. pl/informacje_kep/6991.1,Przemowienie_Przewodniczacego_Konferencji_Episkopatu_Niemiec_Kardynala_Reinharda_Marxa_na_uroczystosci_Konferencji_Episkopatow_Polski_i_ Niemiec_z_okazji_50_lecia_historycznej_wymiany_listow.html.

${ }^{22}$ Marx, „Przekazujmy”, 10. 
Dzisiaj, po 50 latach od tamtego wydarzenia, żyjemy w zupełnie innym, nowym świecie, w wolnej i niepodległej Polsce, razem z Niemcami w zjednoczonej w dużym stopniu Europie, która prawie przez 50 lat cieszyła się pokojem. Fundamentalne prawo, na którym wspiera się wszelki pokój, określił Jan Paweł II w swoim Orędziu na XXXV Światowy Dzień Pokoju w roku 2002, po terrorystycznym ataku na World Trade Center w Nowym Jorku:

Nie ma pokoju bez sprawiedliwości

i nie ma sprawiedliwości bez przebaczenia ${ }^{23}$.

Jest to najbardziej kompletny i magisterialny dokument dziś już św. Jana Pawła II na temat „Chrystusowej nauki o przebaczeniu”. Termin ,przebaczenie” występuje w nim aż 45 razy. Podejmuje on takie tematy jak: „sprawiedliwość i przebaczenie, kultura przebaczenia, duch przebaczenia, potrzeba i polityka przebaczenia, a nawet pedagogia przebaczenia”. Wydaje się, że wszystkie zasygnalizowane tematy i zakresy mogą stać się przedmiotem zainteresowania i pogłębienia pedagogiki oraz wychowania chrześcijańskiego. Orędzie to, w obliczu współczesnych aktów terroryzmu o wymiarze na niespotykaną dotychczas skalę, które wywołały - według określenia papieża Franciszka - „trzecią wojnę światową w kawałkach”, może, a nawet powinno zostać odczytane jako szczególny znak czasu, który przynagla do podjęcia tych tematów.

Wiadomo jednak, że przebaczenie nie jest teorią. Ma ono swoje głębokie korzenie religijne i teologiczne, zakłada pogłębioną i żywą wiarę oraz angażuje całą sferę egzystencjalną człowieka. Wymaga to oczywiście odpowiedniego wychowania, przygotowania i formacji duchowej. Takie wysiłki w ramach polsko-niemieckiej współpracy naukowej były już podejmowane w przeszłości, między innymi pomiędzy Wydziałem Teologicznym Uniwersytetu Warmińsko-Mazurskiego w Olsztynie a Wydziałem Teologii Praktycznej Wyższej Szkoły w Vechta (Dolna Saksonia) ${ }^{24}$. Można żywić nadzieję, że podjęcie tematu pojednania polsko-niemieckiego w kontek-

23 Jan Paweł II, „Orędzie na XXXV Światowy Dzień Pokoju 2002 r.”, w: Dzieła zebrane, t. 4: Konstytucje apostolskie, listy motu proprio i bulle, orędzia na światowe dni, red. Paweł Ptasznik (Kraków: Wydawnictwo M, 2006), 834-839.

${ }^{24}$ Egon Spiegel, „Katecheza - most między Polską a Niemcami w kontekście kościelnych i państwowych inicjatyw pojednania. Przeszłość - teraźniejszość - przyszłość”, w: Pojednanie i polityka. Polsko-niemieckie inicjatywy pojednania $w$ latach sześćdziesiatych XX wieku a polityka odprężenia, red. Friedhelm Boll, Wiesław J. Wysocki, Klaus Ziemer, współpraca Thomas Roth (Warszawa: Wydawnictwo Neriton, 2010), 335-344. 
ście 50-lecia wymiany listów biskupów polskich i niemieckich może przyczynić się do ożywienia lub wznowienia podobnych inicjatyw naukowo-dydaktycznych.

Owocem procesu zbliżenia, pojednania, dialogu i współpracy, u źródła którego stoi przebaczenie biskupów Polski, tak ciężko doświadczonej II wojną światową, na które odpowiedzieli przebaczeniem biskupi niemieccy, w szerszym tego słowa znaczeniu jest faktycznie nowy, społeczny i polityczny ład Europy. Ten akt heroicznego zawierzenia Bogu i gotowość udzielenia przebaczenia zrodziła w mocy Ducha Świętego błogosławione owoce. Ich dalszym następstwem był zarówno wybór Jana Pawła II na papieża (powszechnie wiadomo, że został wybrany przy poparciu między innymi biskupów niemieckojęzycznych), powstanie Niezależnego Samorządnego Związku Zawodowego „Solidarność”, a w jego konsekwencji również zburzenie muru berlińskiego, który dzielił Niemcy i Europę.

Dzisiaj narody doświadczone rozdarciem i tragedią wojen, konfliktów i aktów terrorystycznych, jak: Ukraina, Bośnia i Hercegowina, Korea, a nawet Republika Chińska (Tajwan), pytają: w jakim stopniu doświadczenie pojednania pomiędzy Polską a Niemcami, zapoczątkowane odważnym aktem przebaczenia i pojednania, może być źródłem inspiracji także dla nich? Mogłem tego doświadczyć między innymi w czasie jubileuszowego międzynarodowego sympozjum z okazji 50-lecia wymiany listów, zorganizowanego w Rzymie 26 października 2015 roku.

Podstawową wartością Kościoła jest na zawsze życie Ewangelią i dawanie świadectwa wierze. Chociaż

w niektórych wypadkach wydaje się nawet - jak stwierdza papież Franciszek w bulli Misericordiae vultus ogłaszającej Nadzwyczajny Jubileusz Miłosierdzia - iż znika już samo słowo przebaczenie. Jednak bez doświadczenia przebaczenia pozostaje nam droga bezpłodna i sterylna, jakbyśmy żyli w jakimś miejscu pustynnym i odosobnionym. Nadszedł znowu czas dla Kościoła, aby przyjąc na siebie radosne głoszenie przebaczenia. (...) Przebaczenie bowiem to siła, która przywraca do nowego życia i dodaje odwagi, aby patrzeć w przyszłość z nadzieją ${ }^{25}$.

Potrzeba nam jednak żywej wiary naszych wielkich poprzedników sprzed pół wieku, wytrwałej modlitwy, ale także stałości i determinacji w mocy Ducha Świętego w obliczu nowych, nie mniejszych wyzwań i trud-

${ }^{25}$ Franciszek, Bulla Misericordiae vultus, 10, L'Osservatore Romano 5 (2015): 8. 
ności, by jedyny Pan dziejów, ludzi i narodów, „u którego wszystko jest możliwe" (Mt 19, 26), pozwolił doczekać równie błogosławionych owoców przebaczenia i pojednania, także u progu pełnego niepokojów i niepewności XXI wieku.

\section{Forgiveness and Reconciliation between Poles and Germans as a Gift and Task. 50 Years after the Exchange of Letters of Polish and German Bishops (Summary)}

The article shows the importance of "The Message of the Polish bishops to their German brothers in Christ's pastoral office" (November, 18 1965) in the history of Polish-German reconciliation. This Message contained the famed phrase "we forgive and ask for forgiveness" directed, at the conclusion of Vatican II, to the German bishops by representatives of the people, who were the victim of World War II. This phrase, over the past fifty years, had become a source of some confusions first, but, eventually, it brought to the peoples and to the believers of Churches living in Poland and Germany blessed fruits, which were the foundations for further Polish-German relations. It is therefore not strange that this Message of Polish bishops is now considered by many historians as the most important document of the postwar period.

The article, in its four parts, reveals religious themes, efforts and activities of Polish bishops which aimed at deepening the sense of forgiveness and reconciliation in the midst of shaping the attitudes of the faithful living in the Roman Catholic Church in Poland. The decisive event in this respect - apart from Vatican II - was the celebration of 1000th anniversary of the Baptism of Poland, celebrated at Jasna Gora in Czestochowa on 3th May 1966, under the leadership of the Primate of Poland Stefan Cardinal Wyszynski. Further sections of the article show a long and laborious process of ripening of the forgiveness in the dimension of community and society. This process is illustrated by other - this time common - documents Polish and German bishops issued on the occasion of the 30th (1995) and 40th anniversary (2005) of first "Message", and recently culminated with a solemn celebration of Polish and German bishops in Czestochowa, on November, 222015 and completed by the first joint Message of Polish and German Presidents. The process of rapprochement, dialogue and reconciliation, which began with a collective act of forgiveness has led to far-reaching political changes, lasting peace in Poland and much of Europe. Presented in the article's Messages and their impact on Polish and German societies clearly show that there is no peace without justice, but - as well - there is no justice without forgiveness. 
Key words: Polish-German reconciliation; "We forgive and ask for forgiveness"; The Message of the Polish and German bishops; Millennium of the Baptism of Poland; Stefan Cardinal Wyszynski; Archbishop Karol (Cardinal) Wojtyła; Archbishop Boleslaw Kominek.

\section{Przebaczenie i pojednanie pomiędzy Polakami i Niemcami jako dar i zadanie. W 50 lat po wymianie listów biskupów polskich i niemieckich (Streszczenie)}

Artykuł ukazuje rolę, jaką w dziejach pojednania polsko-niemieckiego odegrało „Orędzie biskupów Polski do ich niemieckich braci w Chrystusowym urzędzie”, z 18 listopada 1965 roku. Zawarte w nim sformułowanie ,przebaczamy i prosimy o przebaczenie" skierowane na zakończenie II Soboru Watykańskiego do biskupów niemieckich przez przedstawicieli narodu, który był ofiarą II wojny światowej, w ciągu minionych 50 lat stało się najpierw źródłem nieporozumień, ale ostatecznie przyniosło narodom i Kościołowi żyjącemu w Polsce oraz Niemczech błogosławione owoce, które stały się fundamentem dalszych polsko-niemieckich relacji. Nie jest więc rzeczą dziwną że wielu historyków to właśnie orędzie biskupów Polski uznało za najważniejszy dokument okresu powojennego.

Artykuł w czterech punktach ukazuje religijne motywy, wysiłki i działania, głównie biskupów Polski, zmierzające do pogłębienia sensu przebaczenia i kształtowania postawy pojednania pośród rzeszy wiernych żyjących w Kościele katolickim w Polsce. Decydujące znaczenie miały w tym względzie - obok Soboru - obchody 1000-lecia Chrztu Polski, celebrowane na Jasnej Górze w Częstochowie 3 maja 1966 roku, pod przewodnictwem Prymasa Polski Stefana kard. Wyszyńskiego. Dalsze fragmenty artykułu ukazują długotrwały i mozolny proces dojrzewania wspólnotowego i społecznego wymiaru przebaczenia. Proces ten ilustruje kolejne, tym razem wspólne dokumenty biskupów Polski i Niemiec z okazji 30-lecia (1995) i 40-lecia (2005), uwieńczone uroczystą celebracją biskupów Polski i Niemiec w Częstochowie 22 listopada 2015 roku, dopełnione pierwszym wspólnym przesłaniem Prezydentów Polski i Niemiec. Proces zbliżenia, dialogu i pojednania, który rozpoczął się zbiorowym aktem przebaczenia, doprowadził do daleko idących zmian ustrojowych, długotrwałego pokoju w Polsce i dużej części Europy. Nie ma bowiem pokoju bez sprawiedliwości, ale nie ma też sprawiedliwości bez przebaczenia.

Slowa kluczowe: pojednanie polsko-niemieckie; ,przebaczamy i prosimy o przebaczenie"; orędzie biskupów Polski i Niemiec; tysiąclecie (Millenium) Chrztu 
Polski; Stefan kard. Wyszyński; Arcybiskup Karol (kard.) Wojtyła; Arcybiskup Bolesław Kominek.

\section{Bibliografia}

Boll, Friedhelm. „Krag z Bensbergu i Memorandum Polskie. Od Soboru Watykańskiego II do poparcia socjalliberalnej polityki odprężenia". W: Pojednanie i polityka. Polsko-niemieckie inicjatywy pojednania w latach sześćdziesiatych XX wieku a polityka odprężenia, red. Friedhelm Boll, Wiesław J. Wysocki, Klaus Ziemer, współpraca Thomas Roth, 72-110. Warszawa: Wydawnictwo Neriton, 2010.

Duda, Andrzej, Joachim Gauck. „Kościoły wyprzedziły politykę”. Wspólne przesłanie prezydenta Rzeczypospolitej Polskiej i prezydenta Republiki Federalnej Niemiec na spotkanie Biskupów Episkopatów Polski i Niemiec w Częstochowie z okazji 50. rocznicy powstania „Orędzia polskich biskupów do ich niemieckich braci w Chrystusowym urzędzie pasterskim” z 18 listopada 1965 r. Wiadomości KAI 48 (2015): 8-9.

Franciszek. Bulla Misericordiae Vultus. L'Osservatore Romano 5 (2015): 4-15.

Gądecki, Stanisław, Reinhard Marx. „Budować przyszłość w duchu przeżytego pojednania”. Wspólne oświadczenie przewodniczących Konferencji Episkopatów Polski i Niemiec z okazji 50. rocznicy wymiany listów z 1965 r. Wiadomości KAI 48 (2015): 6-7.

Gądecki, Stanisław. „Bogu niech będą dzięki za nasze dzisiejsze spotkanie”. Przemówienie w kaplicy Domu Pielgrzyma podczas uroczystości z okazji 50. rocznicy listu biskupów polskich do niemieckich. Wiadomości KAI 48 (2015): 11-12.

Glemp, Józef, Karl Lehmann. „Wspólne słowo polskich i niemieckich biskupów z okazji 30. rocznicy wymiany listów (1965-1995)". L'Osservatore Romano 2 (1996): 56-59.

Greschat, Martin. „Od Memorandum Tybińskiego (1961) do ratyfikacji układów wschodnich (1972). Protestancki wkład w pojednanie z Polską". W: Pojednanie i polityka. Polsko-niemieckie inicjatywy pojednania $w$ latach sześćdziesiqtych XX wieku a polityka odprężenia, red. Friedhelm Boll, Wiesław J. Wysocki, Klaus Ziemer, współpraca Thomas Roth, 29-49. Warszawa: Wydawnictwo Neriton, 2010.

Jan Paweł II. „Orędzie na XXXV Światowy Dzień Pokoju 2002 r.”. W: Dzieła zebrane, t. 4: Konstytucje apostolskie, listy motu proprio i bulle, orędzia na światowe dni, red. Paweł Ptasznik, 834-839. Kraków: Wydawnictwo M, 2006.

Jan Paweł II. Apel jasnogórski, 19 czerwca 1983 r. W: Dzieła zebrane, t. 9: Homilie 
i przemówienia z pielgrzymek - Europa, cz. 1: Polska, red. Paweł Ptasznik, 233-236. Kraków: Wydawnictwo M, 2008.

Krawczak, Tadeusz. „Orędzie biskupów polskich w ocenie struktur partyjnych i Służby Bezpieczeństwa”. W: Pojednanie i polityka. Polsko-niemieckie inicjatywy pojednania w latach sześćdziesiatych XX wieku a polityka odprężenia, red. Friedhelm Boll, Wiesław J. Wysocki, Klaus Ziemer, współpraca Thomas Roth, 152-157. Warszawa: Wydawnictwo Neriton, 2010.

Lipscher, Winfried. „Współpraca Kościołów Polski i Niemiec. Wymiana listów biskupów polskich i niemieckich a wyzwania przyszłości”. W: Pojednanie i polityka. Polsko-niemieckie inicjatywy pojednania $w$ latach sześćdziesiatych XX wieku a polityka odprężenia, red. Friedhelm Boll, Wiesław J. Wysocki, Klaus Ziemer, współpraca Thomas Roth, 345-354. Warszawa: Wydawnictwo Neriton, 2010.

Madajczyk, Piotr. „Recepcja w Polsce niemieckiej reakcji na orędzie biskupów”. W: Pojednanie i polityka. Polsko-niemieckie inicjatywy pojednania $w$ latach sześćdziesiatych XX wieku a polityka odprężenia, red. Friedhelm Boll, Wiesław J. Wysocki, Klaus Ziemer, współpraca Thomas Roth, 177-188. Warszawa: Wydawnictwo Neriton, 2010.

Marx, Reinhard. „Przekazujmy pojednanie dalej”. Homilia przewodniczącego Episkopatu Niemiec, wygłoszona podczas Mszy Świętej odprawionej z okazji 50-lecia wymiany listów między Episkopatami Polski i Niemiec. Wiadomości KAI 48 (2015): 9-10.

Marx, Reinhard. Przemówienie wygłoszone w Częstochowie na uroczystości Konferencji Episkopatów Polski i Niemiec z okazji 50. rocznicy wymiany listów. http://episkopat.pl/informacje_kep/6991.1,Przemowienie_Przewodniczacego_ Konferencji_Episkopatu_Niemiec_Kardynala_Reinharda_Marxa_na_uroczystosci_Konferencji_Episkopatow_Polski_i_Niemiec_z_okazji_50_lecia_historycznej_wymiany_listow.html.

Mechtenberg, Theo. „Pojednanie wbrew przeciwnościom”. „Inicjatywy polskie” Kościołów w NRD. W: Pojednanie i polityka. Polsko-niemieckie inicjatywy pojednania $w$ latach sześćdziesiatych XX wieku a polityka odprężenia, red. Friedhelm Boll, Wiesław J. Wysocki, Klaus Ziemer, współpraca Thomas Roth, 270-288. Warszawa: Wydawnictwo Neriton, 2010.

Michalik, Józef, Karl Lehmann. Wspólne oświadczenie Konferencji Episkopatów Polski i Niemiec z okazji 40. rocznicy wymiany listów między oboma episkopatami w roku 1965. Warszawa: Wydawnictwo Jedność, 2005.

„Orędzie biskupów polskich do ich niemieckich braci w Chrystusowym urzędzie pasterskim". W: Listy pasterskie Episkopatu Polski 1945-2000, cz. 2, red. Piotr Libera, Andrzej Rybicki, Sylwester Łącki, 2217-2226. Marki-Struga: Michali- 
neum, 2003. Faksymile „Orędzia” w: Pamięć i przebaczenie. Orędzie biskupów polskich do biskupów niemieckich i jego reperkusje, red. Damian Bednarski, 164-173. Katowice: Księgarnia św. Jacka, 2015.

„Pozdrowienie biskupów niemieckich dla polskich braci w biskupim posłannictwie i odpowiedź na list z dnia 18 listopada 1965 roku”. W: Listy pasterskie Episkopatu Polski, 1945-2000, cz. 2, red. Piotr Libera, Andrzej Rybicki, Sylwester Łącki, 2227-2230. Marki-Struga: Michalineum, 2003.

Raina, Peter. „Te Deum” narodu polskiego. Obchody tysiqclecia chrztu Polski 1966/67. Olsztyn: Warmińskie Wydawnictwo Diecezjalne, 1991.

„Słowo biskupów polskich o listach do Episkopatów na temat Millenium”. W: Listy pasterskie Episkopatu Polski 1945-2000, cz. 2, red. Piotr Libera, Andrzej Rybicki, Sylwester Łącki, 2231-2237. Marki-Struga: Michalineum, 2003.

Spiegel, Egon. „Katecheza - most między Polską a Niemcami w kontekście kościelnych i państwowych inicjatyw pojednania. Przeszłość - teraźniejszość - przyszłość". W: Pojednanie i polityka. Polsko-niemieckie inicjatywy pojednania w latach sześćdziesiatych XX wieku a polityka odprężenia, red. Friedhelm Boll, Wiesław J. Wysocki, Klaus Ziemer, współpraca Thomas Roth, 335-344. Warszawa: Wydawnictwo Neriton, 2010.

Wojtyła Karol. Kazanie w kościele św. Szczepana, Kraków, 26 grudnia 1965 r.

W: Odnowa Kościoła i świata. Refleksje soborowe, red. Andrzej Dobrzyński, 298-303. Kraków-Rzym: Wydawnictwo św. Stanisława BM, 2011.

Wojtyła, Karol. Kazanie w katedrze wawelskiej, 25 grudnia 1965 r. W: Odnowa Kościoła i świata. Refleksje soborowe, red. Andrzej Dobrzyński, 288-297. Kraków-Rzym: Wydawnictwo św. Stanisława BM, 2011.

Wolff-Powęska, Anna. „O aktualność dialogu i pojednania w stosunkach polsko-niemieckich". W: Pojednanie i polityka. Polsko-niemieckie inicjatywy pojednania w latach sześćdziesiatych XX wieku a polityka odprężenia, red. Friedhelm Boll, Wiesław J. Wysocki, Klaus Ziemer, współpraca Thomas Roth, 355-367. Warszawa: Wydawnictwo Neriton, 2010.

Wyszyński, Stefan. Fragment życzeń wygłoszonych w bazylice katedralnej św. Jana w Warszawie, 25 grudnia 1965 r. W: Budowniczy mostów pojednania. Kardynat Bolesław Kominek (1903-1974), red. Patryk Gołubców, Urszula Pohl, Bożena Sobota, 146-147. Wrocław: Wydawnictwo TUM Wrocławskiej Księgarni Archidiecezjalnej, 2015.

Ziemba, Władysław. Stefan Kardynał Wyszyński. Biografia w fotografiach. Orchard Lake: Zakłady Naukowe Seminarium Polskiego, 1969.

Żaryn, Jan. „Katolicy koncesjonowani a recepcja orędzia biskupów w Polsce”. W: Pojednanie i polityka. Polsko-niemieckie inicjatywy pojednania $w$ latach sześćdziesiatych XX wieku a polityka odprężenia, red. Friedhelm Boll, Wiesław 
J. Wysocki, Klaus Ziemer, współpraca Thomas Roth, 158-176. Warszawa: Wydawnictwo Neriton, 2010.

Żurek, Robert. „Bolesław Kominek - autor orędzia pojednania biskupów polskich”. $\mathrm{W}$ : Pojednanie i polityka. Polsko-niemieckie inicjatywy pojednania $w$ latach sześćdziesiatych XX wieku a polityka odprężenia, red. Friedhelm Boll, Wiesław J. Wysocki, Klaus Ziemer, współpraca Thomas Roth, 50-62. Warszawa: Wydawnictwo Neriton, 2010.

Żurek, Robert. „Wymiana listów między episkopatami Polski i Niemiec w 1965 roku". W: Pojednanie i polityka. Polsko-niemieckie inicjatywy pojednania w latach sześćdziesiatych XX wieku a polityka odprężenia, red. Friedhelm Boll, Wiesław J. Wysocki, Klaus Ziemer, współpraca Thomas Roth, 63-71. Warszawa: Wydawnictwo Neriton, 2010. 